UDC 631:356

\title{
EXPERIMENTAL RESEARCH ON VIBRATIONAL DIGGING-UP OF SUGAR BEET
}

\author{
V. V. Adamchuk ${ }^{1}$, V. M. Bulgakov ${ }^{2}$, I. V. Holovach ${ }^{2}$, Ye. I. Ignatiev ${ }^{3}$ \\ ${ }^{1}$ National Scientific Center "Institute for Agricultural Engineering and Electrification” NAAS of Ukraine \\ 11, Vokzalna Str, vil. Hlevakha-1, Vasylkivsky District, Kyiv Region, Ukraine, 08631 \\ ${ }^{2}$ National University of Life and Environmental Sciences of Ukraine \\ 15, Heroyiv Oborony Str., Kyiv, Ukraine 03041 \\ ${ }^{3}$ Tavria State Agrotechnological University \\ 18, B. Khmelnytskoho prov., Melitopol, Zaporizhzhia Region, Ukraine, 72310 \\ e-mail:vbulgakov@meta.ua
}

Received on November 28, 2017

\begin{abstract}
The technological process of vibrational digging-up of sugar beet has spread in many sugar beet-sowing countries. The experience of using this process demonstrated its advantages compared against other ways of digging-up, but there have been scarce experimental researches of the vibrational digging-up of sugar beet from soil which makes this topic urgent for sugar beet production. Aim. The experimental determination of rational parameters and modes of the vibrational digging-up working tool to ensure the required quality of conducting the technological process of digging sugar beet from soil. Methods. The methods of planning a multifactor experiment, field studies, statistical processing, regression analysis of the experimental data with building graphic curves were applied. Results. A new model of a tool for vibrational digging-up of sugar beet from soil has been elaborated. The accepted program and method were used to conduct experimental research on the impact of the main construction and technological parameters of the vibrational digging-up working tool of the beet harvester on the quality indices of performing the technological process of harvesting sugar beet. The energy parameters of new vibrational digging-up working tools were studied in field conditions via registering the values of tenzometric sensors in different modes of the device and different parameters and working modes of the vibrational digging-up tools. Conclusions. It was established that there is a value of the vibration frequency and running depth in soil of the vibrational digging-up working tool for each value of the translational velocity of the vibrational digging-up machine which corresponds to minimal losses and damage to crop roots. It was also found that the degree of crop root damage depends on the conditions of performing the technological process of vibrational digging-up (soil solidity and humidity), and the weight of damaged crop roots increases with the increase in solidity and the decrease in humidity of soil.
\end{abstract}

Keywords: vibrational digging-up, field experiment, sugar beet, crop root, damage, losses.

DOI: 10.15407 /agrisp5.01.030

\section{INTRODUCTION}

The conditions, required for the technological process of beet harvesting, are ensuring the performance, decreasing the energy losses and increasing the quality of the harvested products. As for beet harvesters, the required condition of ensuring the quality of performing the technological process is avoiding the damage to crop roots while they are dug up, first and foremost.

(C) V. V. ADAMCHUK, V. M. BULGAKOV, I. V. HOLOVACH, Ye. I. IGNATIEV, 2018

Therefore, there is a need to investigate the process of vibrational digging-up and to use its results to determine kinematic and constructive parameters of the digging-up working tools on condition of avoiding damage to the crop roots.

The technological process of vibrational digging-up of sugar beet has spread in many sugar beet-sowing countries. Many years of using this process demonstrated a number of its advantages compared against other methods of digging-up. Therefore, this technological process requires further detailed analytical and 


\section{EXPERIMENTAL RESEARCH ON VIBRATIONAL DIGGING-UP OF SUGAR BEET}

experimental research which will lay the foundation for the elaboration of improved vibrational digging-up working tools.

Substantial theoretical research on the process of vibrational digging-up of crop roots was done in the works [1-4], but only the works [5] and [6] present some experimental results of the impact interaction of pendulum impact testing machine and a crop root. The analysis of scientific literature [7-10] demonstrated that quality indices of digging-up sugar beet from soil are paid considerable attention in Europe. As stated above, there have been scarce experimental researches on the process of vibrational digging-up of sugar beet from soil, therefore, this topic is urgent for sugar beetgrowing industry, as this research can allow improving the most energy-consuming technological process.

The aim of the research is the experimental determination of rational parameters and modes of the vibrational digging-up working tool to ensure the required quality of conducting the technological process of digging-up sugar beet from soil.

\section{MATERIALS AND METHODS}

A new model of the vibrational digging-up working tool was designed for experimental research on the process of vibrational digging-up of sugar beet from soil which was deemed to ensure quality extraction of crop roots from dry and solid ground. The construction design of the vibrational digging-up machine is protected with the Patent of Ukraine for an invention [11] Fig. 1.

The digging-up machine consists of digging-up blades (1), installed on the ends of the mounts (2), which are connected via suspension brackets (3) to the drive mechanism (4) of the mentioned blades (1) to obtain the vibrational movement. The mechanism (4) has a device, which can be used to set (regulate) the frequency and amplitude of the vibrational movements of blades in a wide range of values (the frequency is regulated from 8.5 to $20.3 \mathrm{~Hz}$, the amplitude - from 8 to $24 \mathrm{~mm}$ ). The suspension bracket (3) of the mounts (2) was equipped with an additional hinge which allows for free movements of coupled mounts (2) in a small range in the longitudinal-transversal plane. This ensures the automatic installation of blades (1) during the translational movement of the vibrational diggingup machine.

The general view of the designed vibrational diggingup working tool is presented in Fig. 2.

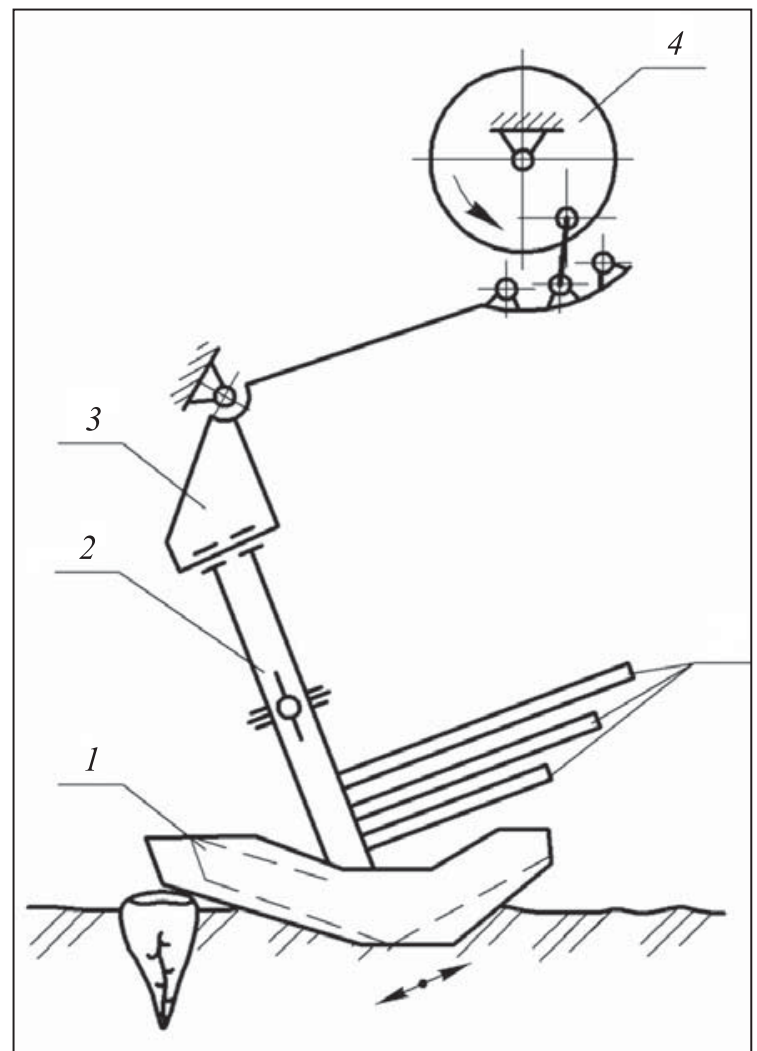

Fig. 1. The construction and technological scheme of the vibrational digging-up machine: 1 - a digging-up blade; 2 mounts; 3 - mechanism of regulating the distance between blades; 4 - vibrational drive mechanism with the mechanism of regulating the amplitude and the frequency of blade vibrations; 5 - guide pins
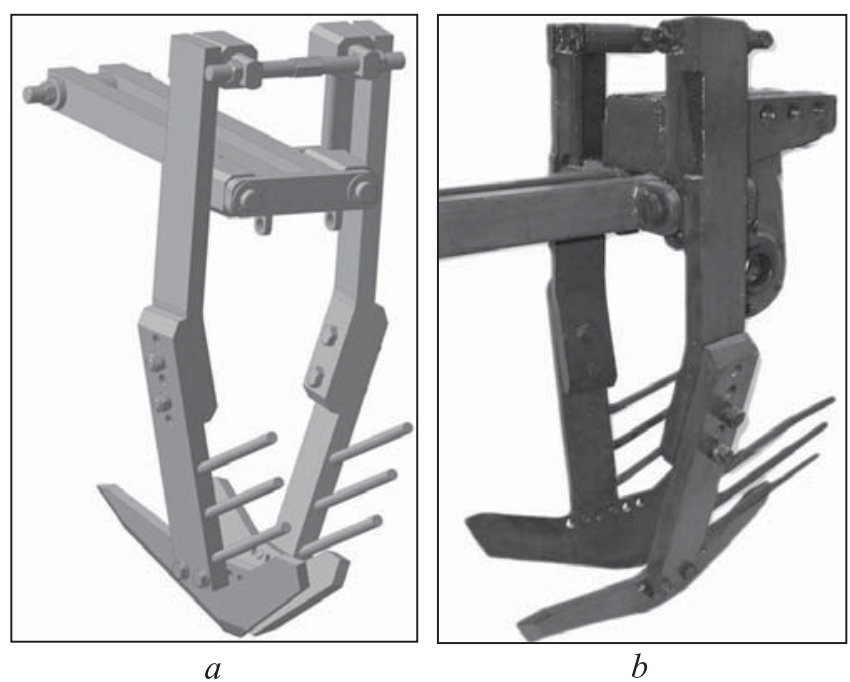

Fig. 2. The general view of the vibrational digging-up working tool: $a$-computerized 3D model; $b-$ a photograph A towed four-row beet harvester was produced for laboratoryfield experimental research of the vibrational digging-up working tool under different parameters and working modes of the vibrational working tool (Fig. 3) 

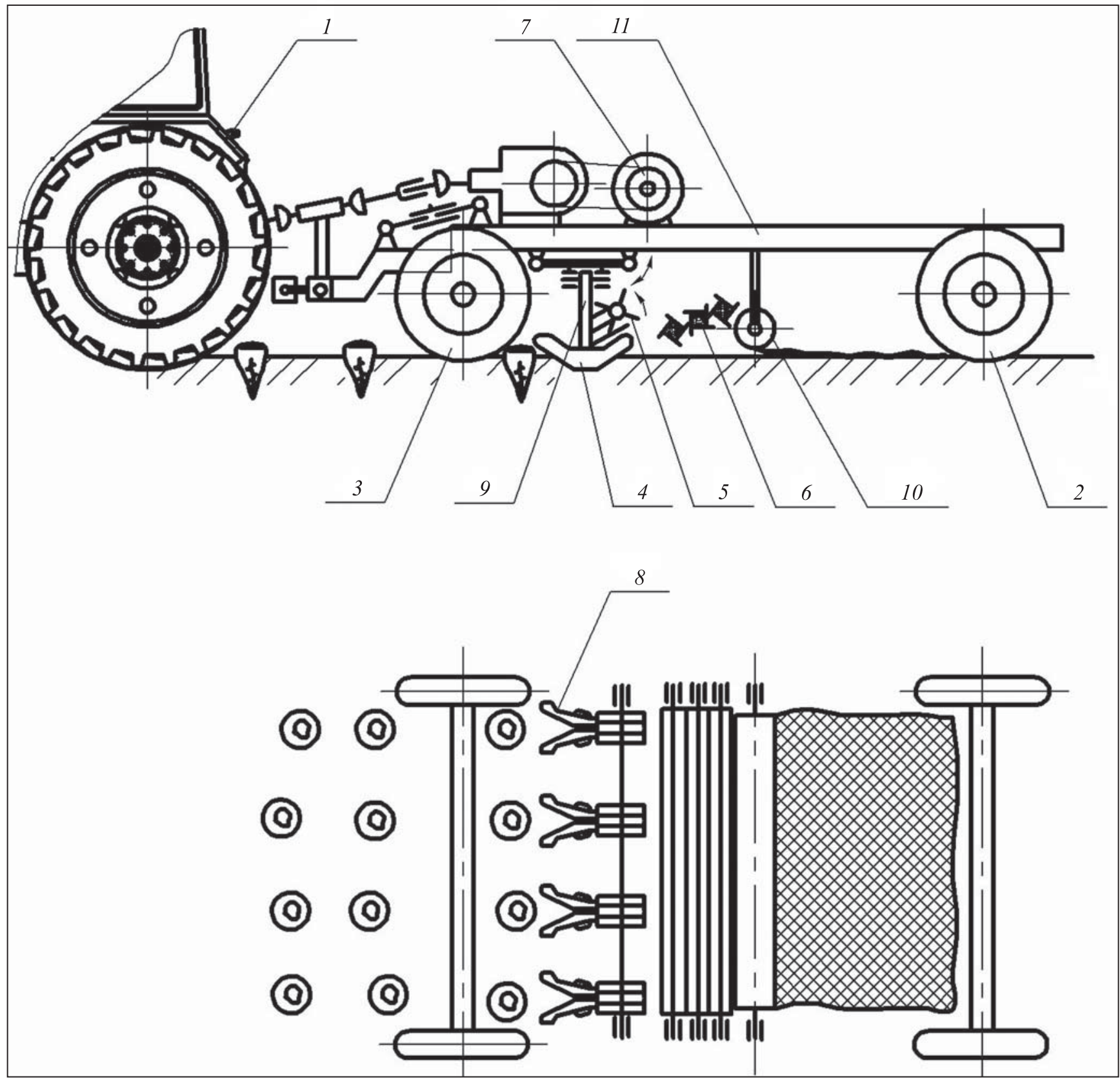

Fig. 3. The scheme of the field experimental device to investigate the vibrational digging-up working tools: $1-$ a wheeled tractor; 2 - posterior supporting wheels; 3 - front (copying) wheels; 4 - vibrational digging-up working tools; 5 - beater; 6 four-blade beater transporter; 7 - drive mechanism of vibrational digging-up working tools; 8 - digging-up blades; 9 - blade mounts; 10 - tape roll; 11 - frame

The experimental device (Fig. 3) consists of the frame (11), bearing on posterior (2) supporting and front (3) copying wheels. The front part of the frame (11) has the installed vibrational digging-up working tools (4), formed by digging-up blades (8), set on the mounts (9). The posterior necked part of blades (8) has a beater (5) with a 4-blade beater transporter (6) behind it. The vibrational digging-up working tools (4) are connected to the drive mechanism (7) for oscillatory movements with a wide range of amplitudes and frequencies.

To determine the energy-force characteristics, a tenzometric traction link was attached to the device for simultaneous measurement of the horizontal and vertical components of the traction effort on the towed device with a wheeled tractor (1). Foil tenzometric sensors were installed on the mounts (9) to determine the ef- 


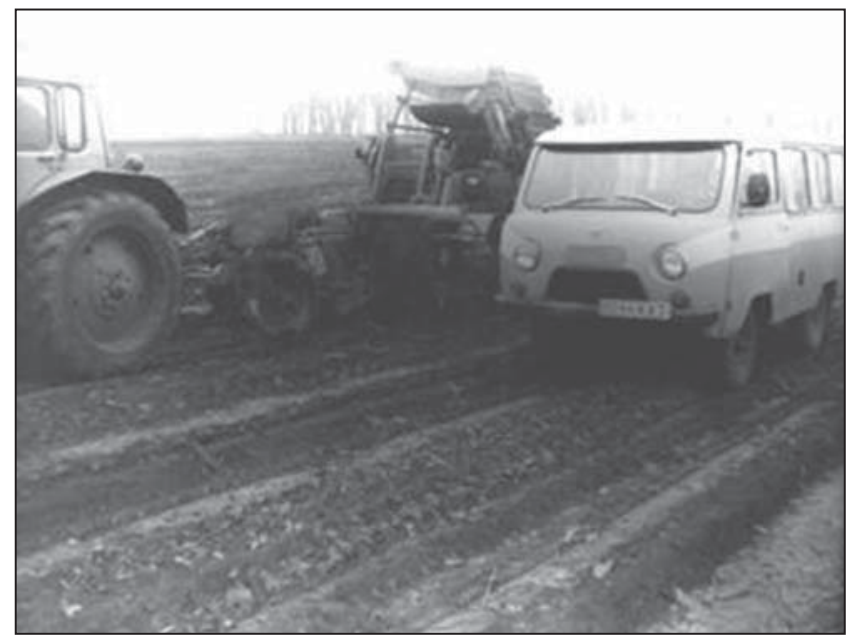

$a$

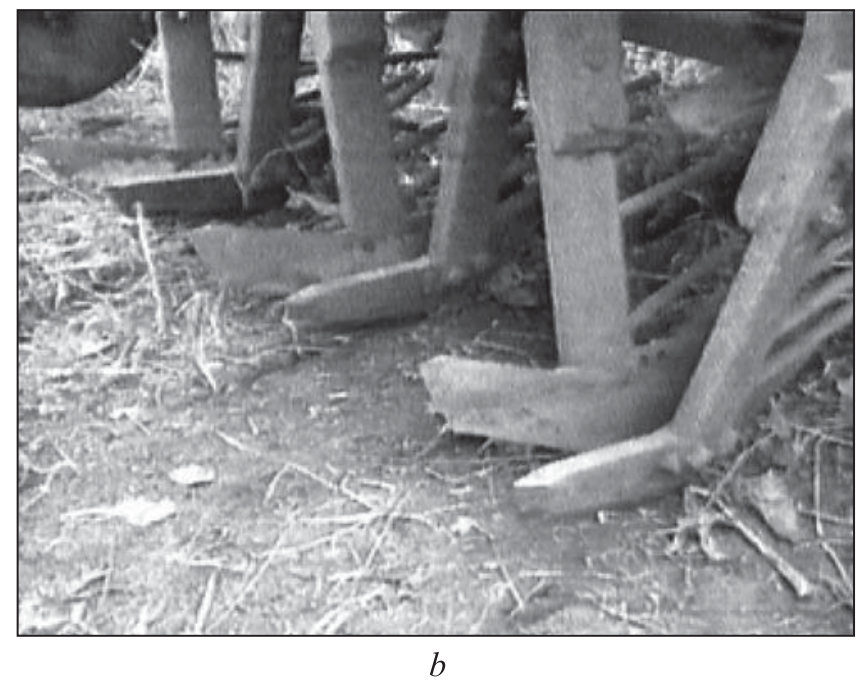

Fig. 4. The laboratory field experimental device $(a)$ to investigate the vibrational digging-up working tools $(b)$

forts of the interaction between the blades (8) and soil. The drive of all the working tools of the experimental device was ensured by the power take-off shaft of the wheeled tractor (1), class 1.4. To define the angular velocity, the steering torque and the power, transmitted to the working tools, an electric joint dynamometer was installed between the power take-off shaft of the tractor (1) and the drive shaft of the working tools of the experimental device. The general view of the experimental device during field experimental research and that of the vibrational digging-up working tools under investigation is presented in Fig. 4. A movable tenzometric station, installed on a vehicle, was moving along the laboratory field device during the experimental research.

During the work of the experimental device, the digging-up blade (8) takes a complicated load, estimated by the value of the bending motion of its mount (9) with the installed tenzometric sensors. A track-measuring wheel is attached to the frame to determine the velocity of the experimental device.

The registration of tenzometric indices of the investigated parameters within the energetic estimation of the work of vibrational digging-up machines was conducted using the movable tenzometric laboratory ChEK-1 (based on UAZ vehicle) which was moving along the experimental device during the experiments (Fig. 4, a). This laboratory allows measuring, registering and demonstrating the average values of power and velocity parameters via six independent measuring channels immediately after the experiments.

The cleaning and transporting working tools of the beet harvester were disconnected from the drive mecha- nism. A device for stripping the tape to collect the sugar beet, dug up from soil, in order to estimate the quality of their extraction in the field work was installed behind the vibrational digging-up machines. The running depth of the digging-up machine in soil was controlled using the measuring device.

The determination of the agrotechnical indices of the experimental field was conducted according to the general method and the method of the Ukrainian Research Institute of Forecasting and Testing of Equipment and Technologies named after Leonid Pogorilyi [12-15].

To determine the indices of agrotechnical evaluation, three standard plots, $20 \mathrm{~m}$ long and $2.7 \mathrm{~m}$ wide, i.e. having the width of six rows, were indicated along the sugar beet field.

The thickness of weeds in the plot was determined by laying the rectangular frame of $90 \times 111 \mathrm{~cm}$ (the area of $1 \mathrm{~m}^{2}$ ) on two adjacent rows in five repeats along the diagonal of the plot. All the weeds were counted within the rectangular frame and separately in the 20 -cm-wide stripe of the row zone.

Prior to the experimental research, according to the method of determining the quality of beet harvesters [5] the following physical and mechanic properties of crop roots were determined: maximal diameter of a crop root; root length; weight of one root; distance between roots in the row; width of interrow distances; height of crop roots relative to the soil surface; deviation of crop roots from the relative axis line of the row.

The results of experimental research were processed according to the known method of statistical processing of experimental data $[12,14,16]$ with further pre- 
sentation in the form of functional and graphic curves and using the applications for PC.

Field testing of the beet harvester was conducted using the method of a multifactor experiment, which was described in [12-15].

The analysis of scientific literature, theoretical studies and previous testing of the machine were used to determine the rational ranges of factor changes, which have the most considerable impact on the quality of digging up crop roots from soil. Therefore, the velocity of the experimental device was set in the range of $1.3 \ldots 2.55 \mathrm{~m} / \mathrm{s}$, the running depth of the digging up blades in soil fluctuated in the range of $0.06 \ldots 0.12 \mathrm{~m}$, the frequency of the working tool oscillations 8.5 .. 20.3 Hz. The listed factors are independent, thus it is possible to change their values regardless from one another.

A complete three-factor experiment on investigating the impact of the mentioned factors on the quality indices of work was conducted with the corresponding standard matrix.

The impact of three factors on the quality indices of work was described using the results of processing the data of experimental research in regression equations in the form of a polynomial of degree 2 :

$$
\begin{gathered}
Y=b_{0}+b_{1} X_{1}+b_{11} X_{1}^{2}+b_{2} X_{2}+b_{22} X_{2}^{2}+b_{3} X_{3}+ \\
+b_{33} X_{3}^{2}+b_{12} X_{1} X_{2}+b_{23} X_{2} X_{3}+b_{13} X_{1} X_{3},
\end{gathered}
$$

where $b_{0}, b_{1}, b_{11}, b_{2}, b_{22}, b_{3}, b_{33}, b_{12}, b_{23}, b_{13}$ - regression coefficients.

After the matrix of experiment planning was realized on the experimental device, the coefficients for variables were defined using Statistica 6 program.

\section{RESULTS AND DISCUSSION}

During the experiment the agricultural background of the experimental plot had the following parameters: soil type - heavy clay loam, soil solidity - 3.8...4.0 MPa; soil humidity $-6 \ldots 8 \%$; sugar beet density -150 thousand of plants per hectare; average sizes of crop roots: diameter $-0.094 \mathrm{~m}$, length $-0.24 \mathrm{~m}$, weight $-0.9 \mathrm{~kg}$.

The results of experimental research demonstrated that the increase in the frequency of working tool oscillations leads to the decrease in the loss of crop roots with a slight increase in the degree of crop roots in most cases.

The equation of the regression of the dependence between the losses of crop roots $\left(Y_{1}\right)$ and the frequency of working tool oscillations $\left(X_{1}\right)$, running depth of the working tools in soil $\left(X_{2}\right)$ and the velocity of the translational movement of the vibrational digging-up machine $\left(X_{3}\right)$ is as follows:

$$
\begin{gathered}
Y_{1}=12.751-0.365 X_{1}+0.004 X_{1}^{2}+175.545 X_{2}+ \\
+0.912 X_{1} X_{2}+884.748 X_{2}^{2}-5.551 X_{2} X_{3}+0.216 X_{3}^{2},
\end{gathered}
$$

with the squared correlation coefficient (squared multiple correlation) $R^{2}=0.789$; multiple correlation coefficient $R=0.888$; standard deviation $S_{r}=0.508$. For this type of function, regression coefficients are insignificant for factors $X_{3}$ and $X_{1} X_{3}$.

The obtained model was used in the Statistica 6 application to build the surface of the response of crop root loss due to the frequency of oscillations of the working tool and its running depth in the soil for the velocity values of the translational movement of the digging-up machine $1.3 ; 1.75 ; 2.1 ; 2.55 \mathrm{~m} / \mathrm{s}$ and their two-dimensional cross-sections were obtained (Fig. 5).

It was also important to investigate the dependence of the crop root losses on the solidity and humidity of soil during the vibrational digging-up. The beet harvester was tested at the frequency of the working tool oscillations of $8.5 \mathrm{~Hz}$. The study of the loss of sugar beet losses depending on the velocity of the translational movement $\left(X_{1}\right)$ and the running depth of the working tools $\left(X_{2}\right)$ was also studied under different working conditions.

The following regression equation was obtained for the soil solidity of $3.8 \mathrm{MPa}$ and its humidity of $8.0 \%$ :

$$
\begin{gathered}
Y_{4}=0.401+9.242 X_{1}+131.572 X_{2}-71.088 X_{1} X_{2}+ \\
+1015.235 X_{2}^{2},
\end{gathered}
$$

at $R^{2}=0.950 ; R=0.975 ; S_{r}=0.454$.

The model obtained was used to build the response surface and its two-dimensional cross section (Fig. 5).

As seen from the obtained charts (Fig. 5), the losses increase with the increase in the velocity of the translational movement of the digging-up machine and decrease with the increase in the running depth in soil. This is explained by the fact that the higher velocity of the translational movement of the digging-up machine is, the fewer crop roots are taken by the working tool (the frequency of $8.5 \mathrm{~Hz}$ provides for this capture less with the increase in the translational velocity), the more crop roots remain either not captured or broken in the tail part. It is clear that the smaller the running depth of the digging-up machine in soil is, the higher is the level of breaking the tail part of crop roots or absence of their capture, which allows for higher losses. When 

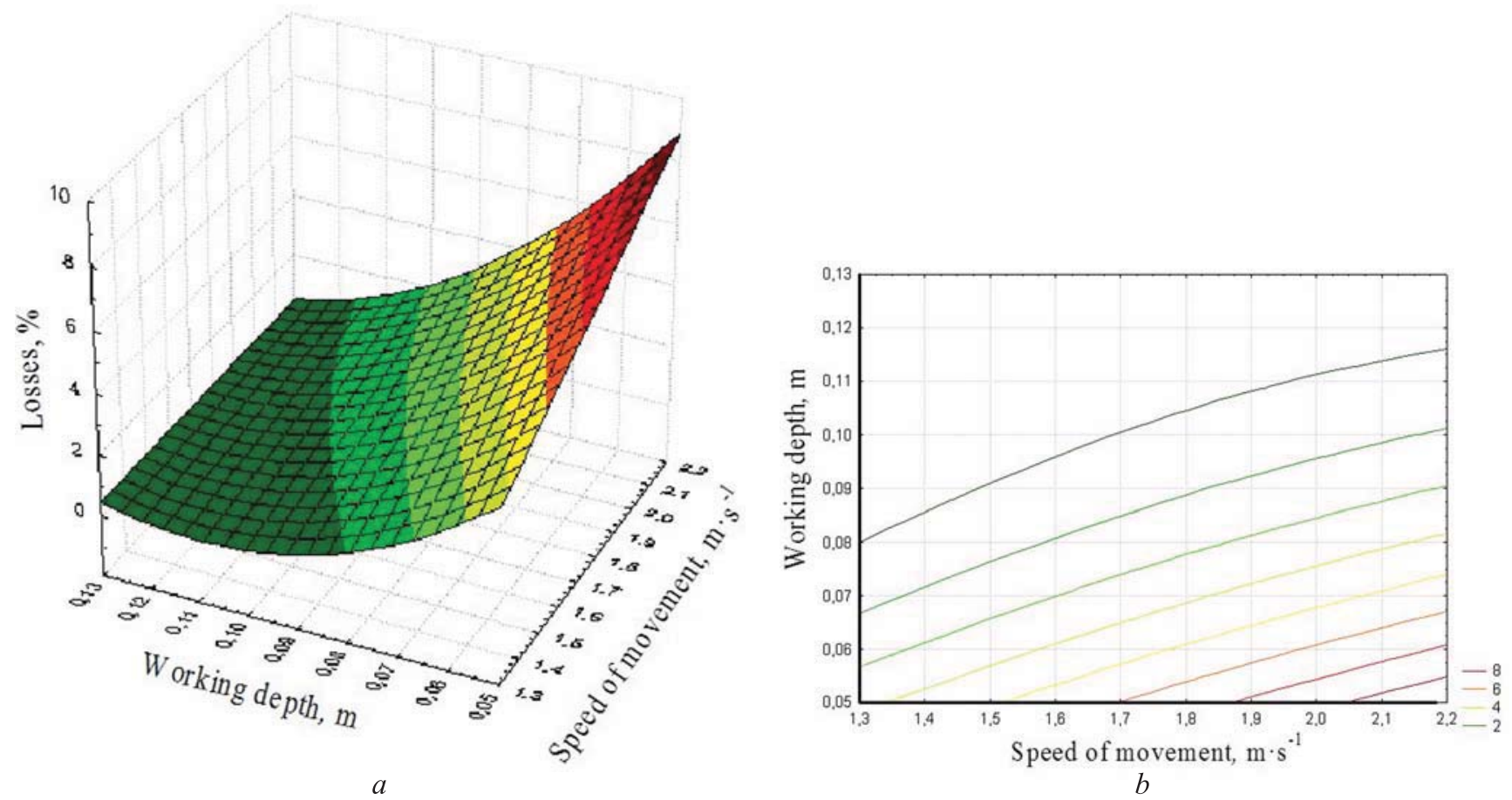

Fig. 5. The square area of the response $(a)$ and the two-dimensional cross-section of the square area of the response $(b)$ of the loss of crop roots due to the velocity of the translational movement of the digging-up machine and its running depth in soil (at the frequency of the working tool oscillations of $8.5 \mathrm{~Hz}$; soil solidity of $3.8 \mathrm{MPa}$; soil humidity of $8.0 \%$ )

the digging-up machine moves at a higher depth, the impact of the translational velocity on the value of the crop root losses decreases due to breaking the tail part at a higher depth, thus this loss is smaller in percentage and less dependent on the velocity of the translational movement of the digging-up machine. The loss is minimal for the running depth of $0.11 \mathrm{~m}$ in soil.

The following regression equation was obtained for the soil solidity of $2.0 \mathrm{MPa}$ and its humidity of $20.0 \%$ :

$$
\begin{gathered}
Y_{5}=-7.75+231.582 X_{2}+3.301 X_{1}^{2}-94.891 X_{1} X_{2}- \\
-682.32 X_{2}^{2},
\end{gathered}
$$

at $R^{2}=0.869 ; R=0.932 ; S_{r}=0.674$.

The graphic presentation of the losses of crop roots depending on the velocity of the translational movement of the digging-up machine and its running depth in soil under these conditions is presented in Fig. 6.

As seen from the presented chart (Fig. 6), in case of the running depth of the working tool in soil of $0.06 \ldots 0.09 \mathrm{~m}$ the losses increase with the rise in the velocity of the translational movement of the digging-up machine, and do not depend considerably on the velocity in case of the running depth of $0.10 \ldots 0.12 \mathrm{~m}$. The reasons are the same as for the previous case. The losses also decrease with the in- crease in the running depth of the working tool in soil and become minimal at the running depth of $0.12 \mathrm{~m}$ in soil.

The obtained experimental data and charts (Fig. 6) demonstrate that the losses for soil with the solidity of $3.8 \mathrm{MPa}$ and the humidity of $8 \%$ are $0.3 \ldots 6.2 \%$; for soil with the solidity of $2.0 \mathrm{MPa}$ and humidity of $20 \%$ the losses of crop roots are in the range of $0.3 \ldots .5 .8 \%$. Therefore, the change in the status of soil in the range of $2.0 \ldots 3.8 \mathrm{MPa}$ and the humidity of $20 \ldots 8 \%$ does not have any considerable impact on the value of crop root losses.

The analysis of the data of the statistical processing of the experiment results demonstrated that there is a value of the vibration frequency and running depth in soil of the vibrational digging-up working tool for each value of the translational velocity of the vibrational working tool which corresponds to minimal losses and damage to crop roots. It was also established that the degree of crop root damage depends on the conditions of performing the technological process of vibrational digging-up (solidity and humidity of soil). The weight of damaged crop roots increases with the increase in solidity and decrease in the humidity of soil. 

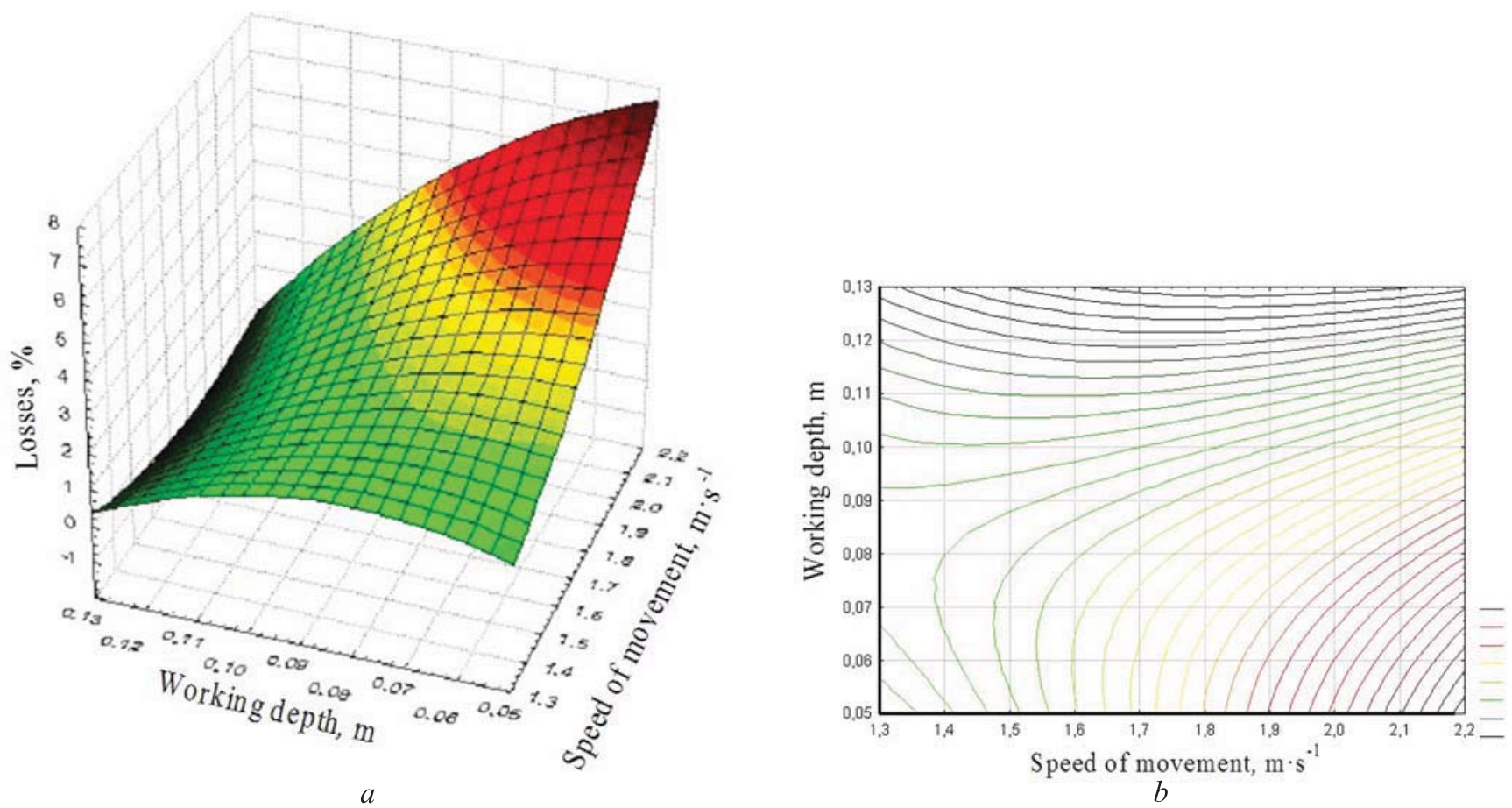

Fig. 6. The square area of the response $(a)$ and the two-dimensional cross-section of the square area of the response $(b)$ of the loss of crop roots due to the velocity of the translational movement of the digging-up machine and its running depth in soil (at the frequency of the working tool oscillations of $8.5 \mathrm{~Hz}$; soil solidity of $2.0 \mathrm{MPa}$; soil humidity of $20.0 \%$ )

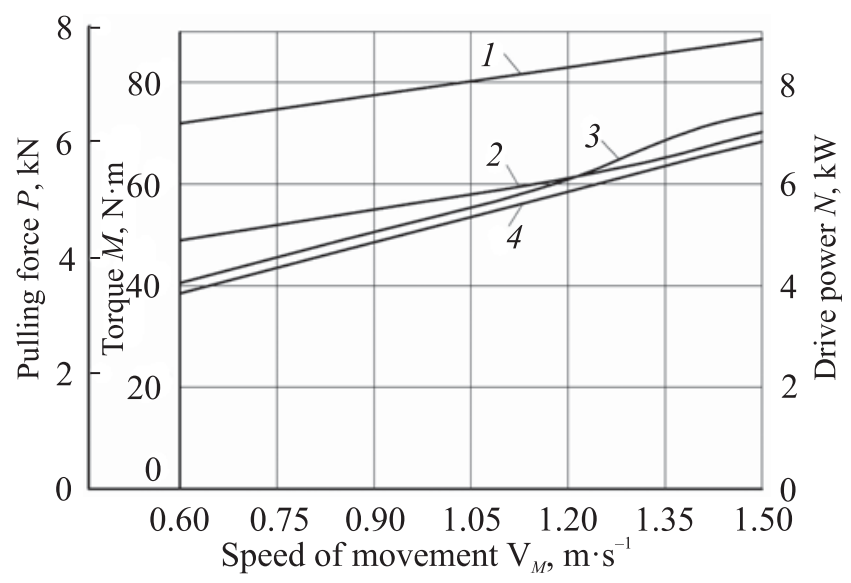

Fig. 7. The energy-power characteristics of the vibrational digging-up working tool (at the frequency of blade oscillations of $8.5 \mathrm{~Hz}$ and the running depth in soil of $0.09 \mathrm{~m}$ ): 1 - towing force; 2 - moment on the power take-off shaft; 3 - thrust power; 4 - power on the drive mechanism of the vibrational digging-up working tool

The experimental research demonstrated that the dirtiness of crop roots, extracted by the vibrational digging-up working tools of the new design is under $1 \%$.

The performance of the beet harvester with the installed new vibrational digging-up working tools under reasonable rational modes of its work was determined by its functioning and duration of stops for repairs, and its efficiency was evaluated by the agrotechnical indices of harvesting sugar beet.

The results of experimental research demonstrated that it is reasonable to use the design of the vibrational digging-up working tool which would ensure the frequency of oscillations of $10 \ldots 18 \mathrm{~Hz}$ and the running depth of $0.08 \ldots 0.10 \mathrm{~m}$ in the range of velocities of the translational movement of the digging-up machine $1.3 \ldots 2.1 \mathrm{~m} / \mathrm{s}$. The mentioned kinematic parameters of work ensure qualitative implementation of the technological process of the vibrational digging-up of sugar beet which corresponds to current agrotechnical requirements regarding losses and damage of crop roots.

The agrotechnical indices of the field plot, where experimental research was conducted to define energy parameters, are presented in the Table.

The investigation on the energy parameters of beet harvester in field conditions was conducted by reading the values of tenzometric sensors under different working modes of the machine and different parameters and working modes of the vibrational digging-up tools. The graphic curves of energy-power characteristics of the vibrational digging-up working tool depending on the velocity of its movement are presented in Fig. 7. 


\section{EXPERIMENTAL RESEARCH ON VIBRATIONAL DIGGING-UP OF SUGAR BEET}

The analysis of the graphic curves demonstrated a shift in the towing force $P$ - curve 1 - from 6.6 to $7.8 \mathrm{kN}$ in the investigated range of velocities (from 0.6 to $1.4 \mathrm{~m} / \mathrm{s}$ ). Therefore, one may consider that the change in the ve- locity of the experimental device conditions the increase in the towing force in a small range. The change of the rotational moment on the power take-off shaft $M$ - curve 2 occurs in the range from 50 to 70 newton-meter.

The agrotechnical indices of the experimental field plot

\begin{tabular}{l} 
Indices \\
\hline Characteristics of a crop: \\
deviation of crop roots from the theoretical axis of \\
the row, \%: \\
$\qquad \begin{array}{l}0 \\
\pm \\
\pm \\
\pm 30 \\
\pm 40\end{array}$
\end{tabular}

$\mathrm{mm}$ and more location of crop root heads relative to the level of soil surface, $\%$ :

$$
\begin{aligned}
& \text { - over }-30 \mathrm{~mm} \\
& \text { - from }-20 \text { to }-30 \mathrm{incl} \text {. } \\
& \text { - from } 0 \text { to }-20 \mathrm{incl} \text {. } \\
& \text { - from } 0 \text { to }+20 \mathrm{incl} \text {. } \\
& \text { - over }+20 \text { to }+40 \mathrm{~mm} \text { incl. } \\
& \text { - over }+40 \text { to }+60 \mathrm{~mm} \text { incl. } \\
& \text { - over }+60 \text { to }+80 \mathrm{~mm} \text { incl. } \\
& \text { - over }+80 \mathrm{~mm}
\end{aligned}
$$

Density of plants, thousands of plants/ha

Biological performance of crop roots, $t / h a$

Biological performance of tops, $t /$ ha

The state of tops on crop roots by the form of leaf location, $\%$

$$
\begin{aligned}
& \text { - rosette } \\
& \text { - semi-rosette } \\
& \text { - cone }
\end{aligned}
$$

Soil type and name by the mechanic composition

Relief

Microrelief

Soil humidity, $\%$ :

$$
\begin{aligned}
& 0-10 \mathrm{~cm} \\
& 10-20 \mathrm{~cm} \\
& 20-30 \mathrm{~cm}
\end{aligned}
$$

Soil solidity, MPa:

$$
\begin{aligned}
& 0-10 \mathrm{~cm} \\
& 10-20 \mathrm{~cm} \\
& 20-30 \mathrm{~cm}
\end{aligned}
$$

Field weediness:

weeds, plants/m2 up to $100 \mathrm{~cm}$ high Predecessor and previous soil tillage

According to the data

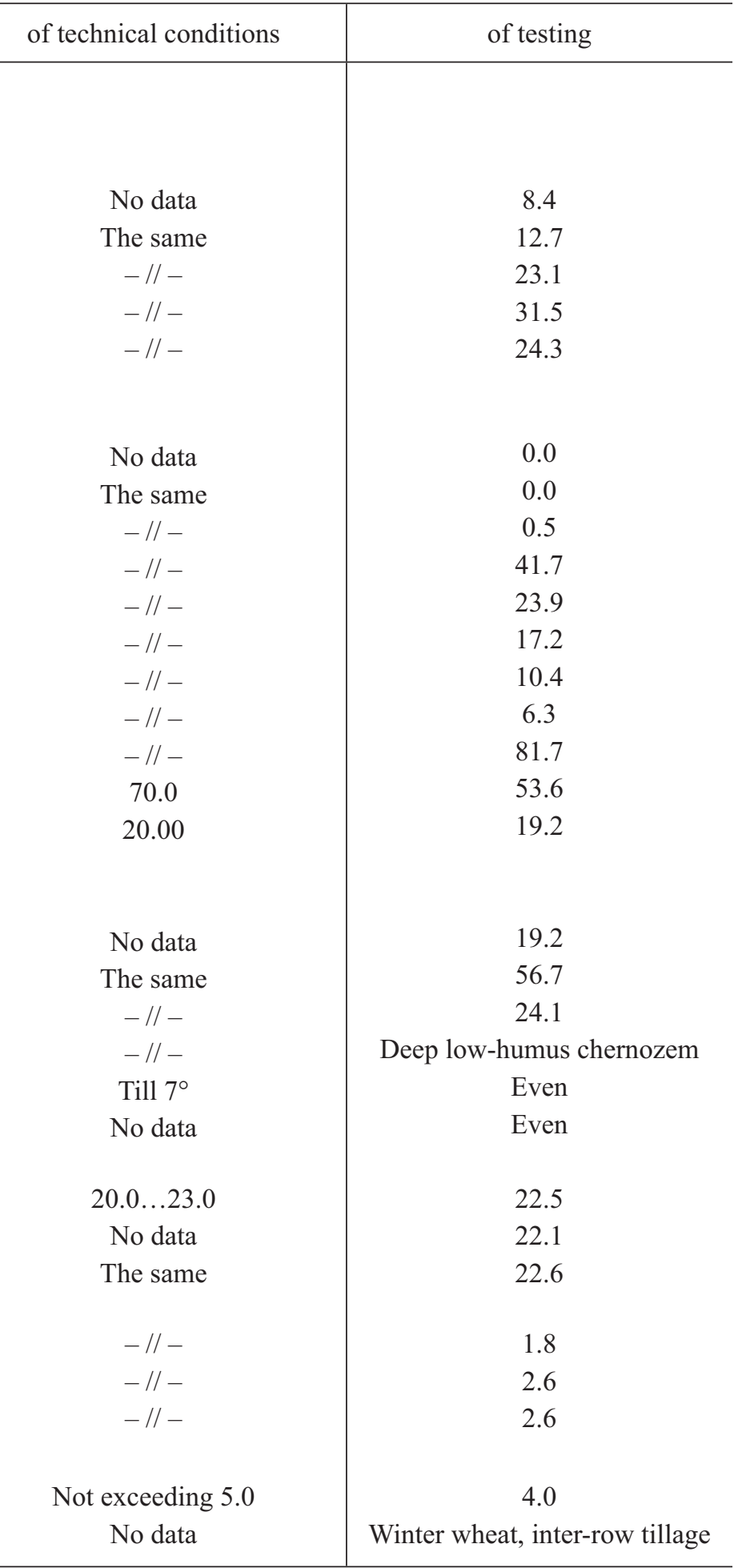


ADAMCHUK et al.

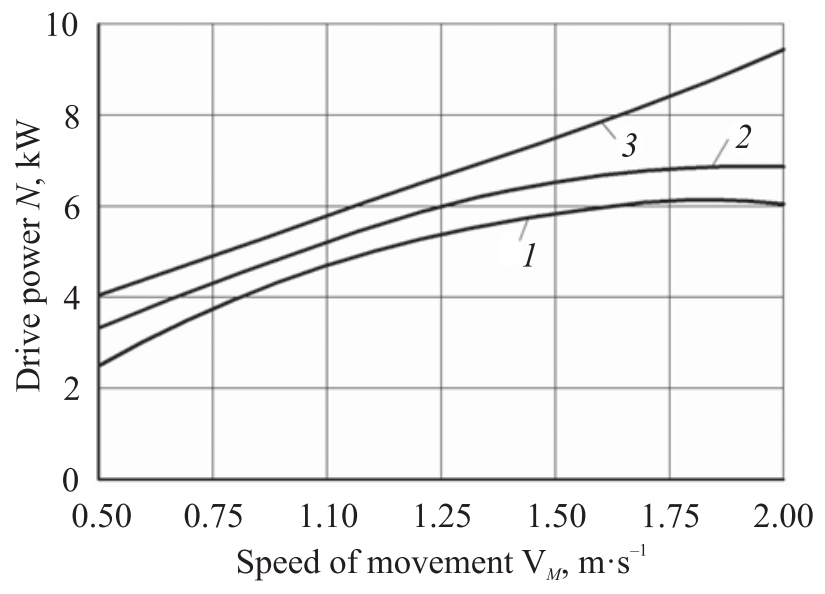

Fig. 8. The dependencies of the power, required for the drive of oscillations, on the velocity of movement and running depth of the digging-up blades in soil (oscillation frequency, $8.5 \mathrm{~Hz}) ; 1-0.06 \mathrm{~m} ; 2-0.09 \mathrm{~m} ; 3-0.12 \mathrm{~m}$

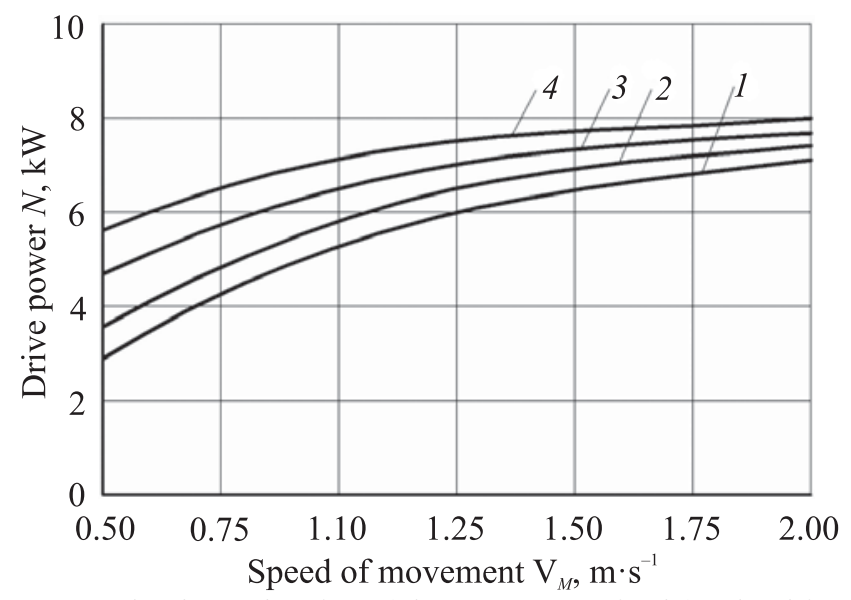

Fig. 9. The dependencies of the power, required for the drive of oscillations, on the velocity of movement and frequency of oscillations of the digging-up blades (running depth $0.09 \mathrm{~m}) ; 1-8.5 \mathrm{~Hz} ; 2-11.0 \mathrm{~Hz} ; 3-15.0 \mathrm{~Hz} ; 4-20.3 \mathrm{~Hz}$

As indicated in [4], when the vibrational digging-up tool is used, the tractive resistance decreases $2.5 \ldots 3.5$ times compared to the resistance of the passive disk digger. Here, the resistance of the vibrational diggingup machine increases less intensively with the increase in the velocity of the translational movement compared to that of the passive disk digger, and even more so that of the passive blade digger, which is proven by the experiment results.

When the towing force $N$ - curve 3, is calculated along with the power on the drive mechanism of the vibrational digging-up working tool $N_{p t o}$ - curve 4 , the graphic curves are built to demonstrate that $N$ and $N_{p t o}$ of the vibrational digging-up working tool change from 4.0 to $7.0 \mathrm{~kW}$.
We built separate graphic curves for the dependence of the power, required for the drive mechanism of the oscillations of the vibrational digging-up working tool, on the velocity of the movement and the running depth of the digging-up blades in soil (Fig. 8) and on the velocity of movement and frequency of oscillations (Fig. 9).

As seen from the curves (Fig. 8), the lowest power, used for the drive of the vibrational digging-up working tools to the oscillatory movements, is present at the frequency of $8.5 \mathrm{~Hz}$ and the running depth of $0.06 \mathrm{~m}$ in soil.

However, considering that the minimal losses and damage of crop roots take place at the running depth of the digging-up machine of $0.09 \mathrm{~m}$ in soil, it is more rational to have the running depth of the digging-up machine of $0.08 \ldots 0.10 \mathrm{~m}$ and the frequency of oscillations of the working tool of $10 \ldots 18 \mathrm{~Hz}$.

\section{CONCLUSIONS}

The experimental research established that the losses of crop roots decrease with the increase in the oscillation frequency of the working tool, and the increase in the velocity of the translational movement leads to their increase. Here, in the range of velocities of the translational movement of the digging-up machine of $1.3 \ldots 2.55 \mathrm{~m} / \mathrm{s}$, minimal losses of crop roots are observed at the running depth of the digging-up machine of $0.09 \mathrm{~m}$, and these losses increase for lower and higher running depth of the digging-up machine.

It was established that at soil solidity of 4.0 MPa and humidity of $8.0 \%$ under the running depth of $0.09 \mathrm{~m}$ in soil and the range of velocities of the translational movement of $1.3 \ldots 2.55 \mathrm{~m} / \mathrm{s}$, the frequency of oscillations of the working tool of $8.5 \mathrm{~Hz}$ does not correspond to the agrotechnical requirements to the loss of crop roots (the losses are $2.7 \%, 1.5 \%$ is acceptable), and, vice versa, the frequencies of 15.7 and $20.3 \mathrm{~Hz}$ meet the requirements (the losses are 0.5 and $0.4 \%$ respectively).

It was experimentally established that at the soil solidity of 4.0 MPa and humidity of $8.0 \%$, and the change in oscillations of the working tool in the range of $8.5 \ldots 20.3 \mathrm{~Hz}$, the damage of beet roots is of changeable nature, but the impact of the change in frequencies on the damage of crop roots is insignificant. There is minimal damage to the crop roots at the running depth of the working tool of $0.09 \ldots 0.10 \mathrm{~m}$. The damages to crop roots increase with the increase in the velocity 


\section{EXPERIMENTAL RESEARCH ON VIBRATIONAL DIGGING-UP OF SUGAR BEET}

of the translational movement of the digging-up machine. For instance, at the velocity of the translational movement of the digging-up machine of $1.3 \mathrm{~m} / \mathrm{s}$ the mass of the damaged crop roots is $8.0 \ldots 9.8 \%$; at the velocity of $1.75 \mathrm{~m} / \mathrm{s}-8.1 \ldots 9.8 \%$; at the velocity of $2.1 \mathrm{~m} / \mathrm{s}-8.2 \ldots 10.3 \%$; at the velocity of $2.55 \mathrm{~m} / \mathrm{s}-$ $10.5 \ldots 12.8 \%$.

The velocity of the translational movement of the digging-up machine in the range of $1.3 \ldots 2.1 \mathrm{~m} / \mathrm{s}$ meets the agrotechnical requirements in terms of damage to crop roots (not more than 10\% are acceptable), but the velocity of $2.55 \mathrm{~m} / \mathrm{s}$ does not meet these requirements.

It was found that the mass of the damaged crop roots depends on the solidity and humidity of soil considerably. For instance, at the solidity of $2 \mathrm{MPa}$ and humidity of $18 \%$ it is in the range of $3.0 \ldots 6.2 \%$, and at the solidity of $4 \mathrm{MPa}$ and humidity of $8 \%$ - in the range of $8.0 \ldots 13.0 \%$.

The application of the vibrational digging-up working tool allows achieving the 2.5...3.5-fold decrease in the relative energy consumption of harvesting compared to the application of the passive disk digger, and even more so - the passive blade digger. It was established that the change in the velocity of the translational movement of the digger conditions the increase in the towing effort in a small range, and the change in the rotational moment on the power take-off shaft at the change in the velocity of the translational movement in the range of $0.5 \ldots 1.4 \mathrm{~m} / \mathrm{s}$ is in the range from 50 to 70 newton-meter.

The smallest power, used for the drive of the vibrational digging-up working tools (providing oscillatory movements), corresponds to the frequency of oscillations of the working tool of $8.5 \mathrm{~Hz}$ and the running depth of $0.06 \mathrm{~m}$ in soil. Considering that the minimal losses and damage of crop roots take place at the running depth of the digging-up machine of $0.09 \mathrm{~m}$ in soil, it is more rational to have the running depth of the digging-up machine of $0.08 \ldots 0.10 \mathrm{~m}$ and the frequency of oscillations of the working tool of $10 \ldots 18 \mathrm{~Hz}$.

It was found that the kinematic working parameters of the vibrational digging-up working tool, ensuring complete extraction of the crop root from soil on condition of avoiding the break of the top part of the root during the impact interaction, which were obtained theoretically, meet the agrotechnical requirements in terms of losses and damage to crop roots completely.
It was established that it is reasonable to use the design of the vibrational digging-up working tool which would ensure the frequency of oscillations of $10 \ldots 18 \mathrm{~Hz}$ and the running depth of $0.08 \ldots 0.10 \mathrm{~m}$ in the range of velocities of the translational movement of the digging-up machine $1.3 \ldots 2.1 \mathrm{~m} / \mathrm{s}$ at the length of the posterior part of the working plant passage of $0.15 \ldots 0.20 \mathrm{~m}$.

\section{Експериментальне дослідження вібраційного викопування коренеплодів цукрових буряків}

В. В. Адамчук ${ }^{1}$, В. М. Булгаков ${ }^{2}$, I. В. Головач ${ }^{2}$, Є. І. Ігнатьєв ${ }^{3}$ e-mail: vbulgakov@meta.ua

${ }^{1}$ Національний науковий центр "Інститут механізації і електрифікації сільського господарства” НААН України

Вул. Вокзальна, 11, Глеваха-1, Васильківський р-н, Київська обл., Україна, 08631

${ }^{2}$ Національний університет біоресурсів і природокористування України

Вул. Героїв Оборони, 15, Київ, Україна, 03041

${ }^{3}$ Таврійський державний агротехнологічний університет

Пр. Б. Хмельницького, 18, Мелітополь, Запорізька обл., Україна, 72310

Технологічний процес вібраційного викопування коренеплодів буряка цукрового набув поширення в багатьох бурякосіяльних країнах світу. Досвід використання цього процесу показав, що він має ряд переваг порівняно 3 іншими способами викопування, але експериментальних досліджень вібраційного викопування коренеплодів цукрового буряку 3 грунту дуже мало, тому дана тематика $є$ актуальною для галузі буряківництва. Мета. Експериментальне визначення раціональних параметрів i режимів вібраційного викопуючого робочого органу для забезпечення необхідної якості виконання технологічного процесу викопування коренеплодів цукрових буряків з грунту. Методи. Застосовано методи планування багатофакторного експерименту, польових досліджень, статистичної обробки та регресійного аналізу дослідних даних з побудовою графічних залежностей. Результати. Розроблено нову конструкцію для вібраційного викопування коренеплодів цукрового буряку 3 грунту. На основі прийнятої програми і методики було проведено експериментальні дослідження впливу основних конструкційних i технологічних параметрів вібраційного викопуючого робочого органу коренезбиральної машини на показники якості виконання технологічного процесу збирання коренеплодів цукрового буряку. В польових умовах досліджено енергетичні параметри нових вібраційних викопуючих робочих органів шляхом реєстрації показників тензометричних 


\section{ADAMCHUK et al.}

датчиків на різних режимах роботи установки та різних параметрах і режимах роботи вібраційних викопуючих органів. Висновки. Встановлено, що для кожного значення поступальної швидкості руху вібраційного копача існує відповідне значення частоти коливань та глибини ходу в грунті вібраційного викопуючого робочого органу, якому відповідають мінімальні втрати та пошкодження коренеплодів. Також встановлено, що ступінь пошкодження коренеплодів залежить від умов виконання технологічного процесу вібраційного викопування (твердості і вологості грунту), причому 3 ростом твердості та зменшенням вологості грунту маса пошкоджених коренеплодів збільшується.

Ключові слова: вібраційне викопування, польовий експеримент, цукровий буряк, коренеплід, пошкодження, втрати.

\section{Экспериментальное исследование вибрационного выкапывания корнеплодов сахарной свеклы}
В. В. Адамчук ${ }^{1}$, В. М. Булгаков ${ }^{2}$, И. В. Головач ${ }^{2}$, Е. И. Игнатьев ${ }^{3}$ e-mail: vbulgakov@meta.ua

${ }^{1}$ Национальный научный центр “Институт механизации и электрификации сельского хозяйства” НААН Украины

Ул. Вокзальная, 11, Глеваха-1, Васильковский р-н, Киевская обл., Украина, 08631

${ }^{2}$ Национальний университет биоресурсов и природопользования Украины

Ул. Героев Обороны, 15, Киев, Украина, 03041

${ }^{3}$ Таврийський государственный агротехнологический университет

Пр. Б. Хмельницкого, 18, Мелитополь, Запорожская обл., Украина, 72310

Технологический процесс вибрационного выкапывания корнеплодов свеклы сахарной получил распространение во многих свеклосеющих странах мира. Опыт использования этого процесса показал, что он имеет ряд преимуществ по сравнению с другими способами выкапывания, но экспериментальных исследований вибрационного выкапывания корнеплодов сахарной свеклы из почвы очень мало, поэтому данная тематика актуальна для отрасли свекловодства. Цель. Экспериментальное определение рациональных параметров и режимов вибрационного выкапывающего рабочего органа для обеспечения требуемого качества выполнения технологического процесса выкапывания корнеплодов сахарной свеклы из почвы. Методы. Применены методы планирования многофакторного эксперимента, полевых исследований, статистической обработки и регрессионного анализа исследовательских данных с построением графических зависимостей. Результаты. Разработана новая конструкция вибрационного выкапывающего органа для вибрационного выкапывания корнеплодов сахарной свеклы из почвы. На основе принятой программы и методики были проведены экспериментальные исследования влияния основных конструкционных и технологических параметров вибрационного выкапывающего рабочего органа корнеуборочной машины на показатели качества выполнения технологического процесса уборки корнеплодов сахарной свеклы. В полевых условиях исследованы энергетические параметры новых вибрационных выкапывающих рабочих органов путем регистрации показателей тензометрических датчиков на разных режимах работы установки и различных параметрах и режимах работы вибрационных выкапывающих органов. Выводы. Установлено, что для каждого значения поступательной скорости движения вибрационного выкапывающего рабочего органа существует соответствующее значение частоты колебаний и глубины хода в почве вибрационного выкапывающего рабочего органа, которому соответствуют минимальные потери и повреждения корнеплодов. Также установлено, что степень повреждения корнеплодов зависит от условий выполнения технологического процесса вибрационного выкапывания (твердости и влажности почвы), причем с ростом твердости и уменьшением влажности почвы масса поврежденных корнеплодов увеличивается.

Ключевые слова: вибрационное выкапывание, полевой эксперимент, сахарная свекла, корнеплод, повреждения, потери.

\section{REFERENCES}

1. Vasylenko P.M., Pogorelyi L.V., Brei V.V. Vibrational way of harvesting crop roots. Mechanization and electrification of socialistic agriculture. 1970;(2):9-13.

2. Bulgakov V.M. Beet harvesters. Monograph. Kyiv: Agrarna nauka, 2011:351 p.

3. Bulgakov V.M., Holovach I.V., Chernovol M.I. Theoretical prerequisites of the study on crop root oscillations during its vibrational digging-up. Construction, production, and exploitation of agricultural machinery. Kirovohrad: KNTU. 2015;45(1):27-43.

4. Holovach I. V. Theory of direct extraction of a crop root from soil at vibrational digging. Bulletin of Kharkiv Petro Vasylenko National Technical University of Agriculture: Coll. of scient. works. 2006; 2(44):77-100.

5. Bulgakov V., Adamchuk V., Kaletnik G., Arak M., Olt J. Mathematical model of vibrational digging-up of root crops from soil / Agronomy Research. Estonian University of Life Sciences. 2014;12(1):51-8.

6. Pogorelyi L.V., Tatianko N.V. Beet harvesters (history, theory, forecast). K.: Phoenix. 2004:232 p.

7. Kenter C., Hoffmann C. Changes in the processing quality of sugar beet (Beta vulgaris L.) during long-term stor- 


\section{EXPERIMENTAL RESEARCH ON VIBRATIONAL DIGGING-UP OF SUGAR BEET}

age under controlled conditions. Int. J. Food Science and Technol., 2009;44:910-7.

8. Merkes R. 50 Jahre Produktionstechnik im Zuckerrübenbau in Deutschland. Zuckerrübe. 2001(4);214-7.

9. Roller $O$. Entblättern statt Köpfen. Zuckerrüben J. Rheinischer Landwirtschafts-Verlag GmbH. 2010;(2):14-5.

10.Zuckerrüben: Erntetechnik und Bodenschutz. FATBerichte Nr. 567. Eidgenössische Forschungsanstalt für Agrarwirtschaft und Landtechnik (FAT), CH-8356 Tänikon TG. 2001:1-19.

11. Pat. of Ukraine No. 74736, A01D25/04. Vibrational digging-up working tool. V.M. Bulgakov, I.V. Holovach. Published on January 16, 2006, Bull. No.1.

12. Vedeniapin S.V. General method of experimental re- search and processing of experimental data. M, Kolos, 1967:159 p.

13. Dospekhov B.A. Method of field experiment (with fundamentals of statistical processing of investigation results). - M.: Agropromizdat, 1985:351 p.

14. Maslov G.G., Didmanidze O.N., Tsybulevsky V.V. Optimization of parameters and working modes of machinery using the methods of experiment planning. Textbook for agricultural higher educational institutions. M.: Publishing House Triada LLC. 2007:292 p.

15. Nadykto V.T. Fundamentals of scientific research. Kherson: Oldi-plus 2017:268 p.

16. Hryshchuk Yu.S. Fundamentals of scientific research: Textbook. Kharkiv: NTU KhPI. 2008:232 p. 